32 Magma

\title{
AUTOR, AUTORIA E AUTORIDADE: ARGUMENTAÇÃO E IDEOLOGIA eM ROLAND BARTHES
}

Calo Gaglard*

Resumo

Esta é uma revisão crítica do artigo "A morte do autor" (1968), de Roland Barthes. A discussão proposta pretende posicionar em situação histórica e ideológica duas questões mais contemporâneas: a comunicabilidade da poesia e a falência da crítica.
Palavras-Chave

Autor, autoria,

intencionalidade.

Abstract

This paper aims to be a critical revision of the well known Roland Barthe's paper "The death of the author" (1968). The preliminaries discussions intends to positioning in historical and ideological contexts two contemporary subjects: poetry communication and decadence of the critic.

* Pós-doutorando no Departamento de Teoria Literária e Literatura Comparada na FFLCH USP. Este artigo compõe o projeto O Império do autor na moderna teoria da literatura - FAPESP, 2007 2008. 
Em memória de meu professor e amigo Haquira Osakabe, que partiu no dia 13 de maio de 2008, data em que dei um ponto final a este artigo, e, há exatos quarenta anos, de quando cerca de 100 mil estudantes e trabalhadores decretaram greve geral na França.

iscuto aqui um dos textos fundamentais a respeito da autoria da obra literária. "Fundamentais", porque se trata do símbolo de uma época em que a teoria da literatura buscou, como em nenhuma outra, afirmar-se como uma ciência do texto, excluindo de seus interesses tudo aquilo que não considerasse próprio da linguagem - um largo espectro que compreende e destaca a figura do autor. Esse pequeno artigo, "A morte do autor" (1968), pode ser lido como um manifesto, e sua enorme repercussão se deve em parte a isso, em parte à chancela de seu autor, Roland Barthes, um dos intelectuais franceses de maior notoriedade na segunda metade do século XX.

A expressão "a morte do autor" chegou a se tornar uma espécie de emblema da crítica estruturalista. Seu caráter peremptório é relativizado, no entanto, pela constatação de que é justamente Barthes, sua figura autoral, um de seus propulsores e constituidores de sentido. Dentre os textos sobre o conceito de autoria, o de Barthes foi aquele que mais radicalmente procurou banir o autor das abordagens literárias, sem, no entanto, ter se libertado da própria autoria. Esse é o índice de utopia de sua tese; aquilo que, afinal, abre uma fissura para a investigação de suas bases.

Passados quarenta anos, aprendemos que ler um texto de acordo com seu autor é uma atitude acrítica, falaciosa do ponto de vista da lógica do texto, mas essa restrição não nos indispõe contra sua figura. O autor não só continua vivo, como o consideramos ponto referencial em nossa cultura, e um dos temas mais controversos entre os estudos literários contemporâneos. Por isso, vale a pena retornar aos termos específicos daquele texto e procurar compreender suas motivações, estratégias e o legado que deixou para a teoria literária contemporânea.

\section{A argumentação}

A tese de que o autor está fora do espaço textual é, antes, o apelo por um novo modo de encarar a escrita: como um campo neutro, responsável pela dissolução 
do sujeito, perda da identidade e destruição de toda a voz. Para argumentar em favor dessa hipótese, Barthes parte da citação de um trecho da novela de Balzac, Sarrasine, que descreve um castrado disfarçado em mulher. A passagem é a seguinte: "Era a mulher, com seus medos repentinos, seus caprichos sem razão, suas perturbações instintivas, suas audácias sem causa, suas bravatas e sua deliciosa finura de sentimentos". O crítico dirige então uma série de perguntas retóricas ao texto, que não são senão parte de uma única indagação:

Quem fala assim? É o herói da novela, interessado em ignorar o castrado que se esconde sob a mulher? É o indivíduo Balzac, dotado, por sua experiência pessoal, de uma filosofia da mulher? É o autor Balzac, professando idéias "literárias" sobre a mulher? É a sabedoria universal? A psicologia romântica? ${ }^{1}$

Diante da constatação de que é impossível identificar o sujeito da enunciação, Barthes conclui que "a escritura é a destruição de toda a voz".

Voltemos então ao trecho citado. Ali, qual é a imagem que se produz da mulher?

Primeiramente, trata-se não mais do que um lugar-comum que a traduz como ser eminentemente instintivo e sensível. O tom empregado no trecho é revelador de uma posição com relação a ela: há a enumeração de cinco características definidoras (seus "medos", "caprichos", "perturbações", "audácias" e "bravatas" são considerados defeitos, porque interpretados como manifestações injustificáveis, daí os qualificativos "repentinos", "sem razão", "instintivas" e "sem causa"), ao passo que, como aparente traço positivo, oferece-se apenas a "deliciosa finura de sentimentos". Notemos: sucedendo a enumeração negativa, o adjetivo "deliciosa" atua sobre o período como uma antífrase, porque seu sentido aponta para a negatividade. À luz do que vem antes, a expressão "finura dos sentimentos" é evidentemente irônica.

No entanto, e segundo o próprio Barthes, se a fala no trecho citado é do narrador, sua autoria é apenas suposta, já que é bem possível que ela atue no campo linguístico do elocutor como uma presença estranha, uma zona de influência da fala de outra personagem ou talvez do próprio autor, entre outras possibilidades. Numa expressão, o narrador pode ter adotado em sua fala uma perspectiva alheia.

Aventemos uma possibilidade de focalização: a de um uso bastante consciente e crítico da expressão "finura de sentimentos". Ela revelaria uma zombaria, revestida de machismo, do qualificativo normalmente atribuído à mulher. A frase encerraria uma apropriação irônica desse lugar-comum, posto que desdenharia dele ao mesmo tempo em que o trataria como atributo. Assim, o início da passagem, "era a mulher", não significaria "era verdadeiramente uma mulher", se "verdadeiramente" for entendido como "uma mulher considerada integralmente, em sua profundidade psicológica", e sim algo similar a "era como as demais mulheres" -

${ }^{1}$ BARTHES, Roland. A morte do autor. O rumor da língua. Trad. Mário Laranjeira. São Paulo: Brasiliense, 1988, p. 65. 
que sofrem, portanto, a estigmatização do autor. Mas se pensarmos, por exemplo, que a focalização se dirige para o herói da novela, segundo outra hipótese do próprio Barthes, seu sentido seria completamente diverso a este.

Esse exercício de atribuições poderia se estender longamente, e ele dá asas à imaginação a partir das sugestões colhidas de Barthes. Mas o que ele revela é que a impossibilidade de fixar uma atribuição autoral (afirmar "é desse modo, e não daquele") não elimina a necessidade de definição de uma autoria para se compreender o sentido do texto; pelo contrário, a interpretação a reclama.

Quem fala assim? Ora, o trecho conforma, de um modo ou de outro, uma imagem autoral. Sua definição está diretamente associada à compreensão do texto. Cogitar que a referida fala represente a visão do próprio autor é uma possibilidade legítima e constatável sem que seja preciso recorrer a nada que esteja fora do espaço textual. Dizer algo do gênero "Balzac quis dizer que..." é uma atribuição que pode ser baseada em indícios textuais, e que oferece um vetor interpretativo para o texto. De modo análogo, para compreender o artigo de Barthes, nós não deveríamos nos perguntar "o que Barthes quis dizer com isso?" É inconcebível que alguém que lance hipóteses, ofereça argumentos, elabore o raciocínio dedutivo e se valha de exemplos, tal como acontece em "A morte do autor", não espere que nos façamos essa pergunta. Por que, então, para Balzac ela não deveria ser feita?

O problema parece estar no alcance e na acepção que se confere ao autor quando a pergunta é feita. Ao indagarmos a respeito do que Balzac pensava, isso é feito sempre na perspectiva do texto. Balzac não é o indivíduo anterior ao texto, mas seu emissor, o sujeito que apenas existe atrelado a Sarrasine. Caso contrário, se o considerássemos como anterior à novela, teríamos de supor absurdamente que Balzac é um indivíduo que jamais mudaria de opinião, com plena convicção de suas posições, e que Sarrasine já era um produto acabado, tal como o conhecemos, em sua mente. O homem evolui, involui, transforma-se afinal, e por isso presumir que tenha coerência absoluta é o mesmo que desumanizá-lo. Há muitos Balzacs. Aquele ao qual dirigimos uma pergunta é a imagem autoral produzida por Sarrasine, o emissor de suas falas, alguém que só existe - e que só pode existir - em conjunto com elas.

Mediante essa ponderação - de filiação, aliás, barthesiana -, podemos afirmar que a interpretação do trecho citado é uma tentativa de responder à seguinte pergunta: o autor procurou produzir sobre o leitor determinado efeito ao denunciar uma visão irônica e machista do sexo feminino, ou será esta realmente a sua visão? Se for esta sua visão, a mulher é o alvo de sua crítica, e o castrado tornou-se, a seu ver, de fato mulher. Mas a crítica à mulher abre a possibilidade de se criticar o crítico. Sendo assim, não seria mais o sexo feminino o alvo, e sim o sujeito que o julga de determinado modo. Consequentemente, o castrado não seria mais que a reprodução do estereótipo feminino. Estamos diante de leituras opostas (e haverá outras), uma direta, a outra enviesada; numa espécie de dilema interpretativo. E essas duas interpretações estão circunscritas na pergunta: qual a perspectiva adotada por Balzac? Ou ainda: quem é o Balzac que fala? 
Essa não é, certamente, uma curiosidade psicológica, mas uma atribuição. Só é possível compreender o trecho respondendo a essa pergunta. Do contrário, se o autor está morto, o sentido está morto.

\section{Quem é o autor?}

$\mathrm{Na}$ acepção que acabou de ser empregada, descobrir o significado é o mesmo que descobrir a intenção - a intenção entendida como um projeto de texto não premeditado, isto é, que vai se formulando e alterando simultaneamente à atividade de escrita. Um projeto que se altera na medida em que o ser humano não pode permanecer o mesmo, indiferente à passagem do tempo, à interferência das circunstâncias, à metamorfose das ideias, que, afinal, é a metamorfose do mundo que o rodeia e o constitui enquanto autor e leitor de seu próprio texto. Uma intenção, portanto, que se ajusta à escrita tanto quanto a escrita se ajusta a ela, porque altera-se conjuntamente o grau de envolvimento do escritor com sua criação, sob influência de tudo o que sente (e sentiu), imagina (e imaginou), conhece (e conheceu), deseja (e desejou). A intenção sofre a ação do texto na mesma medida em que atua sobre ele.

Recusar que a escrita seja uma prática guiada por um propósito, e que esse propósito tenha um peso na sua recepção, é isolar o texto do mundo, negar a literatura como fonte de conhecimento de si e do outro, de troca de experiências e de aproximação das diferenças. Sem intencionalidade, escritor e leitor são seres isolados de tudo aquilo que não diz respeito a si mesmos. Isolados, inclusive, da linguagem. O texto, à luz dessas considerações, é convertido em fetiche: objetual, vazio e distante.

Mas não é esta, a princípio, a acepção que Barthes confere ao autor, e o que se discutiu até aqui é, em boa parte, sobre o que ele deixa de fazer. É preciso, é claro, considerar sobre que contexto atua sua tese, ou, em outras palavras, que conotações carrega o conceito de autoria em seu texto.

O crítico trata o autor como uma "personagem moderna", o que significa que ele é um produto da cultura recente: "ao sair da Idade Média, com o empirismo inglês, o racionalismo francês e a fé pessoal da Reforma, ela (a nossa sociedade) descobriu o prestígio do indivíduo ou, como se costuma dizer mais nobremente, da 'pessoa humana'". ${ }^{2}$ Essa formulação revela um posicionamento ideológico. Por um lado, historicizar o autor significa relativizar seu papel na história da cultura, enfraquecer seu teor de verdade e submetê-lo ao regime de oscilação das circunstâncias. Por outro, lembremos que o termo "moderno" é tomado como sinônimo de "positivista", e este, por sua vez, compreendido como sendo "resumo e ponto de chegada da ideologia capitalista". Eis os pomos da discórdia que se alojam nessa tese. Prestar atenção a eles ajuda a esclarecer algo importante: ao rejeitar o autor, Barthes ataca, numa expressão, o homem burguês e a mentalidade moderna.

${ }^{2}$ Ibid., p. 66. 
A partir desse ponto, para que se entenda o que representa a recente tentativa de exclusão do autor do universo de sentido do texto, talvez seja necessária uma pequena digressão para se considerar o que representa o surgimento do autor do ponto de vista da escritura.

Lembremos que a figura do autor se fortalece à medida que a ideia clássica de gênero se enfraquece na tradição literária. As noções antes vigentes, de unidade de tom e pureza estética, revogavam a separação absoluta entre os diferentes tipos de texto, tal como realizado no Livro III da República, de Platão, mais empiricamente na Poética, de Aristóteles, e na Epistola ad Pisones, de Horácio, que é o texto que talvez mais tenha influenciado a poética e a retórica dos séculos XVI ao XVIII. Ali, o poeta formula a divisa que sintetiza a concepção de gênero: "singula quaeque locum teneant sortita decentem" (que cada assunto ocupe o seu devido lugar).

O enfraquecimento dessa mentalidade não é, em sua origem, um produto do romantismo. Já no barroco espanhol, o surgimento de autores como Lope de Vega e Calderón de la Barca é simultâneo ao de um novo gênero, misto e, portanto, "impuro" - a tragicomédia. A substituição da estética do gênero pela estética do gênio ocorre com mais nitidez no século XVIII. É quando afloram os lugares-comuns românticos em torno da concepção de literatura, que passa a ser progressivamente encarada menos como trabalho ou aplicação de uma técnica, e mais como irrupção da interioridade do poeta (com o Sturm und Drang, na Alemanha).

Estamos no terreno mais que conhecido da historiografia literária, e antes que o leitor se aborreça com seu caráter inevitavelmente generalizante, atentemos para o que ele nos esclarece: se a "verdade do texto" passa a ser identificada no indivíduo que o escreve, a concepção de gênero é historicizada, o que significa dizer que ele se torna passível de evolução, e com isso nega-se seu caráter supostamente estático e normativo.

É nesse sentido que, no prefácio à Estética de Hegel, Lukács lê os gêneros como determinados pelas necessidades das sociedades. Já na correspondência entre Goethe e Schiller se acompanha a transição da ideia de pureza para a de hibridismo. De resto, esse conceito é a pedra de toque do famoso prefácio de Victor Hugo, "Do grotesco e do sublime", que anuncia outra forma híbrida, o drama, como amálgama entre opostos.

Essa síntese, necessariamente esquemática, é suficiente para atender a um propósito específico, que é o de afirmar que a ênfase depositada na figura do autor na tradição literária ocidental não tem a mesma conotação que lhe é atribuída por Barthes. Se este prefere entender o autor como limitador do sentido do texto, a recapitulação de seu contexto de origem põe em evidência justamente o contrário dessa concepção: a presença de um novo personagem, o escritor criativo, como parte integrante do universo textual, aponta para a libertação da literatura de suas amarras prescritivas, atuando como um dos vetores da individualidade e autonomia da obra literária.

O alvo de Barthes aparece, portanto, velado. Talvez ele não seja o autor, talvez essa seja a imagem que metaforiza uma outra noção, de origem romântica e relacionada ao autor: a de literatura como confissão, como expressão de um eu. Ela 
não está, evidentemente, desvinculada do autor, mas tem a especificidade de conferir a ele o poder de explicar o texto, de tratá-lo como o esteio do sentido de tudo o que escreve, reduzindo a escrita a um meio diáfano e transparente de registrar um conteúdo pré-formado.

Para refletir sobre essa hipótese, voltemos ao texto de Barthes. Ali ele explicita em que circunstâncias costuma aparecer essa personagem:

O autor reina ainda nos manuais de história literária, nas biografias de escritores, nas entrevistas dos periódicos, e na própria consciência dos literatos, ciosos por juntar, graças ao seu diário íntimo, a pessoa e a obra; a imagem da literatura que se pode encontrar na cultura corrente está tiranicamente centralizada no autor, sua pessoa, sua história, seus gostos, suas paixões; a crítica consiste ainda, o mais das vezes, em dizer que a obra de Baudelaire é o fracasso do homem Baudelaire, a de van Gogh é a loucura, a de Tchaikovski é o seu vício: a explicação da obra é sempre buscada do lado de quem a produziu, como se, através da alegoria mais ou menos transparente da ficção, fosse sempre afinal a voz de uma só e mesma pessoa, o autor, a entregar a sua "confidência".

O trecho é muito claro. Por essa passagem, Barthes identifica como autor o indivíduo que escreve, isto é, o eu biográfico, com data de nascimento, características físicas e hábitos mundanos. Trata-se, primeiramente, de considerá-lo em sua acepção mais restrita, portanto. Essa figura de carne e osso deve representar algo de revoltante para o crítico, mas talvez não seja odiosa em si mesma, porque com a expressão "a morte do autor" Barthes certamente não sugeria o extermínio do escritor criativo. Sua insatisfação é com os procedimentos críticos de seu tempo, responsáveis por desviar a atenção destinada ao texto literário para aquele que o produziu. A crítica de Barthes se dirige, portanto, a uma prática: interpretar segundo as declarações, a biografia e a psicologia do escritor.

Essa prática implica recuperar no texto a experiência vivida (nas biografias, diários íntimos e histórias literárias), ou ajustar o texto às declarações daquele que o escreveu (nas entrevistas e nos documentos revirados no espólio de um escritor). De um modo ou de outro, interpretar segundo o autor significa, portanto, pressupor a coerência do eu individual e buscar a unidade de sentido do texto numa figura ao mesmo tempo anterior (na suposta premeditação consciente ou inconsciente do texto) e posterior a ele (nas declarações ulteriores a seu respeito).

O trecho de Barthes retoma, na verdade, uma discussão um pouco mais antiga, travada com grande propriedade por T. S. Eliot, cuja filosofia crítica, a exemplo de sua poesia, é fundada na concepção de que a natureza humana é "impura" e finita. Conforme salienta A. G. George, em "Eliot as literary critic", seu antecessor principal é Hulme, que repudiava a ideia rousseauniana de que a essência do homem é boa, o "nobre selvagem". Hulme defendia a necessidade da disciplina e da impessoalidade. Se a personalidade humana é impura, a sinceridade e a clareza com que ela é "expressa" não podem constituir critério para se julgar o texto. Daí Eliot

${ }^{3}$ Ibid., p. 66. 
apontar para a necessidade de se estabelecer padrões externos que possam servir como critério de avaliação para a literatura. Em Eliot, a defesa da autonomia estética da literatura entrava, contudo, em conflito com sua religiosidade crescente e sua consciência social. ${ }^{4}$

Explicar é o contrário de interpretar. Se a interpretação atua sobre possibilidades, a explicação presume que só pode haver um sentido, e que este sentido é passível de ser revelado. A interpretação é mutuamente válida: eu interpreto de acordo com algumas justificativas que não excluem uma segunda interpretação, construída com base em outras justificativas. Já a explicação não permite a variedade. Ela é um ponto final em qualquer discussão. A interpretação não assume que possa haver uma verdade imutável, ela trata o texto como um organismo maleável, que se modifica de acordo com o momento histórico de sua recepção e com o próprio leitor, e carrega em si a ideia de que as verdades são ilusões criadas. Já a explicação se move pela satisfação na crença em uma verdade definitiva, pelo mistério ainda maior de uma causalidade única, fria e indiferente à diversidade humana. ${ }^{5}$

Explicar um texto segundo seu autor implica pensar a intenção como uma deliberação premeditada à escrita. A crítica a essa prática, já muito conhecida, e ao menos três décadas mais antiga do que o manifesto de Barthes (lembremos dos ensaios de Eliot, da crítica de Jung a Freud, e da "falácia intencional" de Beardsley e Wimsatt), parte da ideia base de que, se fosse possível explicar um texto segundo a intenção de seu autor teríamos que concordar com a possibilidade de as palavras traduzirem literalmente nossas ideias, e, mais absurdamente, com a hipótese de o escritor ter pensado todo o texto antes de começar a escrevê-lo. Tomada dessa forma, a escrita seria uma consubstanciação, isto é, o mesmo que transportar ideias para o papel, sem que outras ideias (e mesmo outras palavras) interferissem naquilo que foi previamente elaborado mentalmente. Para se compreender a intencionalidade como premeditação requer-se que se adote uma concepção tão somente mecânica da escrita.

Estabelecida essa distinção, Barthes supostamente defenderia a interpretação no lugar da explicação. Mas não é isso o que ocorre, e "a morte do autor" terá implicações mais radicais que esta.

\section{De que é feita a escritura}

Da impossibilidade de ancorar o sentido do texto num porto seguro, estável e definível como é o autor, decorre uma noção bastante flexível de interpretação, que Barthes distingue da decifração, e concebe simplesmente como leitura possível. Em outros termos, a atividade crítica deixa de visar a uma verdade exclu-

\footnotetext{
${ }^{4}$ Cf. Cap. VIII de GEORGE, A. G. T. S. Eliot - his mind and art. London: Asia Publishing House, s/d.

${ }^{5}$ Cf. NIETZSCHE. Sobre verdade e mentira. Org. e trad. de Fernando de Moraes Barros. São Paulo: Hedra, 2007.
} 
dente das demais, e se apresenta como inclusiva, mutuamente verossímil. Segundo Barthes, o texto pode ser "desfiado", nunca "decifrado", porque "não há fundo" que se revele.

Nesse universo teórico, a questão que se coloca não é mais conceitual do que de nomenclatura. Reformular nossos modos habituais de compreender o mundo, bem como nossas práticas de leitura e ensino, significa, nesse debate, reformular o vocabulário que empregamos. O exemplo maior disso é a conversão do conceito de literatura, matizado pelos séculos de tradição retórica, em escritura, concebida como prática que "propõe sentido sem parar", mas com o propósito de "evaporá-lo: ela procede a uma isenção sistemática do sentido". ${ }^{6}$

No universo barthesiano, a suposição de um sentido principal é autoritária. Haver muitos sentidos significa não haver um "sentido último". Esse modo de encarar o texto destitui o crítico de seu trono de leitor profissional, porque desierarquiza sua interpretação ao considerá-la mais uma leitura. Barthes continua a rejeitar as formas de poder, a denunciar os donos do texto, a que se refere com uma ironia, o emprego das maiúsculas alegorizantes: "não é de se admirar, portanto, que o reinado do Autor tenha sido o reinado do Crítico, nem tampouco que a crítica (mesmo a nova) esteja hoje abalada ao mesmo tempo que o Autor."7

Desalojada de um autor - de um passado e de um fundo -, a "escritura" se constituirá como um espaço de "dimensões múltiplas, onde se casam e se contestam escrituras variadas, das quais nenhuma é original: o texto é um tecido de citações, saídas dos mil focos da cultura." Essa passagem em Barthes é seminal para a teoria da intertextualidade, que é uma expressão cunhada por Julia Kristeva, em 1966, e sistematizada como teoria em Semiótica, de 1969. Ali, a noção de intertextualidade vem em substituição à de intersubjetividade, isto é, como forma de designar o processo de produção do texto literário para além da expressão de um eu. O texto se constitui, segundo a semióloga, da absorção e transformação de outros textos. Toda a escrita será, portanto, e inevitavelmente, reescrita. Nesse campo de atuação, entram em jogo, de modo decisivo para se pensar a evolução da tradição literária, noções como as de paródia, paráfrase, citação, colagem, alusão e apropriação, pensadas como formas de rupturas e desvios.

À luz dessas considerações, o "escriptor", segundo Barthes:

não possui mais em si paixões, humores, sentimentos, impressões, mas esse imenso dicionário de onde retira uma escritura que não pode ter parada: a vida nunca faz outra coisa senão imitar o livro, e esse mesmo livro não é mais que um tecido de signos, imitação perdida, infinitamente recuada. ${ }^{8}$

A concepção de que os textos dialogam entre si, e de que a escrita é um arranjo de vozes não é, evidentemente, uma invenção de Barthes, tampouco de Kristeva. Ela existe desde Homero, e a prática da emulação entre autores é mais do que

\footnotetext{
${ }^{6}$ BARTHES, A morte do autor, op. cit., p. 69.

${ }^{7}$ Ibid., p. 69.

${ }^{8}$ Ibid., p. 69.
} 
conhecida. Modernamente, já nas primeiras décadas do século XX, ao menos três teóricos russos trataram do tema com profundidade: Eikhenbaum ("Sobre a teoria da prosa", 1925) e Tinianov ("Da evolução literária", 1927), vinculados ao chamado formalismo russo, e, principalmente, Bakhtin, cujas teorias a respeito do dialogismo do discurso literário e da polifonia no romance (A poética de Dostoiévski, 1929, e Questões de literatura e estética, 1975) conferem o escopo teórico mais denso sobre o tema. Se avaliarmos "A morte do autor" com base em seus antecedentes, encontraremos uma gama tão variada de autores relevantes e de estudos profundos, que seremos levados a concluir que "a morte do autor" é sobretudo um panfleto em favor de um outro polo constituinte do fenômeno literário. ${ }^{9}$

Isso porque a orientação que Barthes confere a seu manifesto não enfatiza o dialogismo, que representa o índice de libertação e inclusão mais interessante em seu texto; em seu lugar, ela aponta surpreendentemente para a construção de um outro império.

\section{O império do Leitor}

Como já adiantado, o tom do texto de 1968 é o de manifesto. A lógica do discurso barthesiano não é estritamente dedutiva - uma proposição não leva necessariamente a outra. Barthes trabalha, melhor dizendo, com um jogo de compensações: "... o autor entra na sua própria morte, a escritura começa". O desligamento do autor é compreendido, nesses termos, como condição necessária para a escritura. Ele afirma, por exemplo, que "nas sociedades etnográficas, a narrativa nunca é assumida por uma pessoa, mas por um mediador, xamã ou recitante, de quem, a rigor, se pode admirar a performance (isto é, o domínio do código narrativo), mas nunca o 'gênio'." Seria possível, diante dessa remissão, contra-argumentar dizendo simplesmente que nossa sociedade não é mais etnográfica, e que escritores não são xamãs, ou então que essa contextualização não é mais verdadeira e aplicável do que as demais, como com a da sociedade romântica, na qual a narrativa é assumida por um único indivíduo, "homem de gênio", cuja obra é admirada em correlação estreita com sua psicologia e experiências. Mas esse caminho seria adequado se Barthes não tivesse revelado seu real propósito com a tese da "morte do autor", que é o de instaurar um outro império: "o nascimento do leitor deve pagar-se com a morte do autor". ${ }^{10}$

Essa é a frase axiomática que encerra seu texto. Trata-se de um apelo, que merece atenção mais detida, porque, se atentarmos bem, ele significa que embora critique o "império do Autor", Barthes não trata a "escritura" como fenômeno integralmente autônomo.

Se "o verdadeiro lugar da escritura" é a "leitura", quem é o leitor? Essa pergunta identifica na estratégia argumentativa de Barthes seu foco tendencioso. Isso

\footnotetext{
9 Antoine Compagnon, em $O$ demônio da teoria, chegou por outras vias à expressão "slogan anti-humanista".

${ }^{10}$ Ibid., p. 70.
} 
porque, se o autor era antes tomado em sua acepção mais restrita - o escritor, o indivíduo -, o leitor é concebido de modo bastante diferente. Primeiramente, ele não é um indivíduo: "o leitor é um homem sem história, sem biografia, sem psicologia". Ele representa, na verdade, um espaço: "onde se inscrevem, sem que nenhuma se perca, todas as citações de que é feita uma escritura". Se assim é, o leitor é aquele que confere unidade ao texto: "a unidade do texto não está em sua origem, mas no seu destino". Um destino impessoal, portanto. Mas não seria possível usar esse mesmo recurso para idealizar o autor?

Em "Escrever a leitura" (1970), Barthes expõe seus propósitos em S/Z, a análise de Sarrasine, afirmando que ao invés de falar de Balzac e do seu tempo, da psicologia de suas personagens, da temática do texto ou da sociologia do enredo, preferiu "ler levantando a cabeça" ", isto é, sistematizando todas as digressões, os momentos que interrompeu a leitura para interrogá-la. $S / Z$ é a demonstração prática do que Barthes chama de "texto-leitura", expressão que substitui o termo "crítica", e que pretende retirar o privilégio ao lugar de onde supostamente parte a obra, pessoal ou histórico, e redirecioná-lo para seu destino, o leitor. Assim, ao invés de se perguntar "o que o autor quis dizer", Barthes pergunta "o que o leitor entende". ${ }^{12}$ Mas nota-se, novamente, em contraste com a descrição da figura autoral, o tratamento idealizador conferido ao leitor: "Não reconstituí o leitor (fosse eu ou você), mas a leitura. Quero dizer que toda a leitura deriva de formas transindividuais." 13

Diante de um postulado a tal ponto dogmático, refaçamos a pergunta: se concordarmos em compreender como equivocado o espaço antes conferido ao autor como autoridade sobre o texto, será legítimo assumir a censura ao autor como substituto da antiga censura ao leitor? Ou ainda: por que tratar o leitor como tutor do sentido do texto seria mais legítimo do que atribuir esse papel ao autor?

Para essa pergunta, é inevitável considerar uma resposta muito simples, mas grávida de decorrências: porque os leitores são muitos, ao passo que o autor é um só. Os leitores, sendo em maior número e diferentes entre si, tornam tudo ao mesmo tempo possível e impossível. Se tudo pode ser comunicado numa frase, o que de fato ela comunica?

O império do leitor não é outra coisa senão uma tentativa inicial de dissolução do sentido e, com ele, do status do texto. Ainda em "Escrever a leitura", lemos: "a composição canaliza; a leitura, pelo contrário (esse texto que escrevemos em nós quando lemos), dispersa, dissemina." O autor, ou a "lógica da razão", é substituído pelo leitor, ou a "lógica do símbolo". ${ }^{14}$ A concepção de que o "texto-leitura" deve reestabelecer a "verdade lúdica" da "escritura" é o substituto no vernáculo

${ }^{11}$ BARTHES, Roland. Escrever a leitura. O rumor da língua. São Paulo: Brasiliense, 1988, p. 40.

${ }^{12}$ Ibid., p. 41.

${ }^{13}$ Ibid., p. 42. Um tratamento "transindividual" conferido ao autor se verifica em Foucault, em "O que é um autor" e em A ordem do discurso, textos de que tratarei noutra ocasião.

$$
{ }^{14} \text { Ibid., p. } 41 .
$$


barthesiano à concepção de que a crítica deve estabelecer a verdade objetiva/subjetiva da literatura. Está aberto, assim, o curso dos questionamentos para que envereda a crítica pós-estruturalista. E essa constatação nos encaminha para um estágio importante nessa discussão.

\section{Pela rota mallarmaica}

A concepção de que a linguagem poética é essencialmente não comunicativa é de origem simbolista e atraiu para o poema uma aura mística, que encontrou amplo respaldo na literatura francesa da segunda metade do século XIX. No entanto, não se pode generalizá-la. Em "The Social Function of Poetry” (1945), T. S. Eliot - conhecido por advogar em favor da despersonalização do escritor no texto, e por antecipar a visão dos new critics, sobretudo no que diz respeito às falaciosas projeções psicobiográfias de críticos como Sainte Beuve - não abre mão do propósito comunicativo para tratar da lírica. O título do livro de que consta este ensaio, Sobre poesia e poetas, é autoexplicativo nesse sentido:

Beyond any specific intention which poetry may have, such as I have already instanced in the various kinds of poetry, there is always the communication of some new experience, or some fresh understanding of the familiar, or the expression of something we have experienced but have no words for, which enlarges our consciousness or refines our sensibility. ${ }^{15}$

Em contraste com a visão eliotiana de que a poesia lida sempre com a comunicação de alguma experiência nova, ou proporciona um novo entendimento do que já é familiar, a concepção de escritura resulta em Barthes num texto que não pode representar nada que esteja antes dele. Essa forma de encarar o texto, como realidade ontológica, não é estranha à sua base de enunciação linguística - a concepção algo misteriosa, mas muito difundida, de "função poética da linguagem", proposta em 1960 pelo linguista russo Roman Jakobson. A linguagem poética não narra, não expressa, porque ela é um fim em si mesma. O que Jakobson afirma é que a "função da linguagem poética projeta o princípio de equivalência do eixo de seleção sobre o eixo de combinação"16 da linguagem. Mas Barthes radicaliza essa perspectiva, por defender que a "verdade do texto" é o próprio texto, não no sentido de que ele possa comunicar algo, mas de que ele, enquanto escritura, só pode ser auto-referencial. Jakobson não foi tão longe: "A adaptação dos meios poéticos a algum propósito heterogêneo não lhes esconde a essência primeira, assim como os elementos da linguagem emotiva, quando utilizados em poesia, conservam ainda sua nuança emotiva." 17

Essa diferença se deve a um viés específico de leitura. O modo como Barthes lê Jakobson, e com ele a Nouvelle critique e o grupo Tel quel, tem em Mallarmé um

${ }^{15}$ ELIOT, T. S. The Social Function of Poetry. On poetry and poets. London - Boston: Faber and Faber, 1984, p. 18.

${ }^{16}$ JAKOBSON, Roman. Linguística e poética. Linguística e comunicação. 5. ed. São Paulo: Cultrix, 1971, p. 130.

${ }^{17}$ Ibid., p. 131. 
filtro radical, que singulariza a linguagem poética como objeto anticomunicativo. "No fundo, o mundo foi feito para acabar num belo livro", dizia o poeta de "Le livre". Em um dos fragmentos de Igitur, lemos ainda: "Profiro a palavra, para afundá-la de novo em sua inanidade". ${ }^{18}$ O caminho de desmistificação do autor prosseguia, pela rota mallarmaica, para a mistificação da linguagem. Estava aí o novo índice de literariedade do texto. Ao invés de pensar os mecanismos próprios de uma função poética da linguagem, a crítica de Barthes cedia à recusa não só da explicação, mas também da interpretação.

A esse respeito, recentemente o ensaísta italiano Alfonso Berardinelli (um intelectual nada "moderno", diga-se de passagem, na medida em que julga que a literatura não só tem um sentido como confere sentido à experiência) tomou partido de modo bastante incisivo nessa questão denunciando a influência e a hegemonia pós-estruturalista enquanto base de teorização do texto literário. Segundo ele, a rota traçada através de Mallarmé teria levado a poesia para um "caminho de depuração anticomunicativa, progressivamente se enfraquecendo e esvaziando". As cores com que Berardinelli pinta o cenário da nova poesia são pálidas: "a maior parte dos jovens autores que começaram a publicar a partir dos anos 1970 não ultrapassaram os limites e o âmbito restrito fixados pela estética formalista e pelas vanguardas informais, segundo as quais tudo era possível em poesia, tudo era permitido, exceto dizer alguma coisa." 19

A leitura teria deixado de ser o compartilhamento de uma experiência nova, uma vez que, simultaneamente às tendências poéticas, Berardinelli constata um danoso movimento de abstração do texto por parte dos críticos. Ele considera que enquanto a crítica literária em pouco tempo ocupou-se, não da literatura, mas da ideia de literatura, sua noção de linguagem traduziu-se como hermetismo, um todo fechado em si mesmo, estranho a quaisquer valores semânticos: "As fronteiras da Literatura, entendida como máquina textual que devora a si mesma, dilatavam-se enormemente, impedindo que a ideia e a essência literária entrassem de fato em atrito com algo de diferente e de estranho". ${ }^{20} \mathrm{O}$ texto torna-se, então, um código restrito a um círculo diminuto de escritores, o que num outro ensaio Berardinelli chama de "antimundo". ${ }^{21}$ Com a literatura ascética e afastada de tudo, a crítica a seu respeito, que havia estigmatizado o fundo semântico da "escritura", converte-se numa fala verborrágica e congectural sobre o silêncio - sua forma mais depurada de autodestruição. Ambas, narcisicamente, formulando jargões inovadores a respeito de si mesmas.

Desmistificava-se o autor, mistificava-se a linguagem. E com isso fazia-se uma negação generalizada: do sujeito, do tema (o objeto), da sociedade, da história; de tudo que não fosse a afirmação de um vazio, ela mesma, linguagem.

\footnotetext{
${ }^{18}$ MALLARMÉ. Poemas. Org. e trad. de José Lino Grünewald. Rio de Janeiro: Nova Fronteira, 1990, p. 115.

${ }^{19}$ BERARDINELLI, Alfonso. As fronteiras da poesia. Da poesia à prosa. Org. e prefácio de Maria Betânia Amoroso. São Paulo: CosacNaify, 2007, p. 16.

${ }^{20}$ Ibid., p. 16.

${ }^{21}$ Ibid., "Quatro tipos de obscuridade", p. 141.
} 
A leitura de Berardinelli, da década de 1990, é afim à perspectiva de Hayden White sobre a crítica contemporânea a um ensaio seu, de 1976, que falava num "momento absurdista" na moderna crítica literária. Para o crítico americano, a crítica não apenas não mais teria um ideia segura do que representava a literatura, como não saberia traçar a linha que separa a literatura da linguagem: "nada é interpretável como fenômeno especificamente literário, a literatura como tal não existe, e a tarefa da moderna crítica literária (se a questão for levada às últimas consequências) é comandar sua própria dissolução." 22

É o caso, então, de voltarmos às bases dessa discussão. Num ensaio esclarecedor sob vários aspectos, "The Frontiers of criticism" (1956), T. S. Eliot chamou a atenção para dois perigos do método explicativo ou psicobiográfico: 1) pressupor que há apenas uma interpretação correta, sem perceber que o poema pode ter significados diferentes para leitores de diferentes sensibilidades; 2) pressupor que sendo válida a interpretação dum poema, ela passa a ser aquilo que seu autor tentara transmitir consciente ou inconscientemente. A tese da "morte do autor" não desconsiderou esses riscos, pelo contrário, ela extrapolou seus limites, e ao se opor em demasia à ótica individualista e histórica das correntes de explicação do texto, acabou por se equiparar à política de certos governantes, que sob o pretexto de eliminarem a pobreza, mais ou menos voluntariamente expulsaram os pobres de suas vistas.

\section{Autoria e autoridade: "fora os rinocerontes"}

O manifesto de Barthes é escrito num momento excepcional, em que Paris é o epicentro de explosões de radicalismo estudantil assistidas em todo o mundo. Quarenta anos depois, não é tarefa simples mensurar o estado de exaltação em que se vivia naquele período, porque a realidade que conhecemos é em muitos aspectos diametralmente oposta àquela. Basta dizer que hoje a tirania do mercado associada à falta de oportunidade de trabalho e ao individualismo levou o jovem a abandonar o discurso revoltado e a lutar justamente pela inserção nesse sistema. A imagem do profissional "bem-sucedido" está andares acima em sua escala de valores daquela outra contestadora, ora malvista como romantismo ultrapassado, sem lenço e sem documento, ora digerida pelo próprio mercado, que a devolve em formas mais domesticadas, com a imagem de Che nas camisetas, pôsteres e broches.

Já em 1972, Pasolini aludia ao regresso dos jovens de sua geração com relação à dos anos sessenta. Para ele, os cabelos compridos, então signos não verbais que, embora nascidos no seio da burguesia, exprimiam o enjoo da civilização de consumo, haviam se tornado "coisas de televisão ou dos anúncios publicitários". Eram então signos que ressuscitavam o conformismo servil e o convencionalismo vulgar que seus pais haviam momentaneamente superado. ${ }^{23}$

\footnotetext{
${ }^{22}$ WHITE, Hayden. "O momento absurdista na teoria literária contemporânea". In: Trópicos do discurso - ensaios sobre a crítica da cultura. São Paulo: Edusp, 1994. p. 286.

${ }^{23}$ PASOLINI, Pier Paolo. O discurso dos cabelos. Os jovens infelizes - antologia de ensaios corsários. Trad. Michel Lahud e Maria Betânia Amoroso. São Paulo: Brasiliense, p. 37-44.
} 
Pasolini, aliás, percebeu, tão logo começou a se agravar, o processo de "coisificação" e "desindentificação" social originado no capitalismo monopolista, e que em termos bem atuais é designado por "globalização". A uniformização dos gostos, hábitos, ideias - ou da falta delas -, trajes, léxico, valores etc., deve-se, em suma, à vontade de aburguesamento social que teria feito da pobreza algo repugnante aos nossos olhos. Passamos a aceitar a música dos pretos, mas não aceitamos os pretos: "Em 1961, os burgueses viam no subproletariado o mal, exatamente como os racistas americanos o viam no universo negro", diz Pasolini. ${ }^{24}$

Como descreve Hobsbawm, o espantoso juvenescimento da sociedade assistido após a década de 1950 significa, ao mesmo tempo, a afirmação absoluta do capitalismo. O jovem, seja pelo rock, pelo jeans, pelo cinema hollywoodiano (James Dean), pelas drogas, pela liberalização sexual, pela tecnologia mutante e acelerada, ou pelo culto do corpo e pela valorização dos esportes, depois da Segunda Guerra passa a ser o símbolo máximo das economias de mercado desenvolvidas. A cultura jovem torna-se a matriz da revolução cultural do século XX e acentua o que Hobsbawm chama de "abismo histórico" entre os nascidos antes de 1925 e depois de $1950 .^{25}$

Hoje, pautado no julgamento das aparências, e formado num sistema educacional pragmatista, esse jovem "bem informado", cujas ansiedades são anestesiadas, quando não confundidas, pelo consumo, ${ }^{26}$ não duvida de nada; prefere, em síntese, a adaptação à contestação. O mass media, ou o "hedonismo do poder consumista", nas palavras de Pasolinni, tornou-se a ideologia do poder no mundo jovem.

Isso para dizer que a escrita de "A morte do autor", realizada justamente em Paris, por um intelectual de espírito jovem (embora já na casa dos cinquenta anos), libertário e contestador, comprometido com as mudanças e os discursos de seu tempo, não pode ser bem compreendida se inteiramente desvinculada de seu momento de produção, caracterizado por uma embriaguez política e cultural cujo raio de disseminação abrange todo o Ocidente.

Entre fevereiro e maio de 68 eclodem os movimentos antisstanilistas em Varsóvia e Praga e as revoltas estudantis em Bonn, na Alemanha, assiste-se à tomada da Universidade de Nanterre, na França, liderada por Daniel Cohn Bendit, à invasão da Universidade de Brasília pelos estudantes e aos protestos em todo o Brasil pela morte do estudante Edson Luiz de Lima Souto, em confronto com a polícia durante a invasão do restaurante universitário Calabouço, no Rio de Janeiro. Nos EUA inicia-se uma onda de conflitos raciais após o assassinato de Martin Luther King, ocorre a ocupação da Universidade de Colúmbia e o protesto contra a guerra do Vietnã no Central Park, em Nova Iorque. Em Paris levantam-se barricadas de até três metros de altura nas ruas do Quartier Latin, e coloca-se em marcha uma sequência de greves operárias que culminam na paralisação, no dia 25 de maio, de

${ }^{24}$ Ibid., Meu "Accattone" na TV após o genocídio, p. 138.

${ }^{25}$ Cf. HOBSBAWM, Eric. Revolução cultural. Era dos Extremos - o breve século XX 1914-1991. Trad. Marcos Santarrita, 2. ed. São Paulo: Companhia das Letras, 1994, p. 314-36.

${ }^{26}$ A esse respeito, Pasolini fala em um novo fascismo, o "fascismo de consumo". 
nada menos que 10 milhões de estudantes e funcionário públicos, considerada a maior da história.

As lutas de 68 foram sempre antiautoritárias. E essa reação contra o poder se estendeu do âmbito político ao familiar, educacional e comportamental. Mas o que as singulariza na França, e torna sua compreensão uma tarefa menos óbvia do que pode aparentar ser, é que o movimento não se resumia, simplesmente, a uma reivindicação financeira dos operários, ou à discórdia política dos estudantes e intelectuais. Há um certo infantilismo que compõe o movimento e o torna inaudito desde a origem: um grupo de estudantes que rejeitavam a disciplina, as regras e as formalidades da vida no campus. E esse espírito muito mais lúdico do que propriamente revolucionário se manteve. A rebeldia, distante do drama do esfomeado ou do desespero aflitivo do desempregado, tal como assistimos hoje no terceiro mundo, era mais propriamente de um colorido niilista de quem não pretendia tomar o poder, mas contestar a existência de qualquer instância que pudesse exercê-lo. E essa contestação poderia se sintetizar na permissão, por exemplo, de as mulheres usarem calças compridas. Sem um projeto político real, sem uma ditadura para combater, e com as barrigas cheias, mais propriamente do que realizar uma revolução, o que a juventude parisiense buscava era um discurso de revolta.

Maio de 68 não triunfou em todos os planos, e o que se assistiu na década de 1970 foi a um endurecimento dos regimes políticos, a tomada de Praga pelos tanques soviéticos, a eleição de Nixon nos EUA, o AI-5 no Brasil e a volta de De Gaulle ao poder na França. Mas seu efeito sobre os costumes e a cultura foi bastante visível. Barthes se referiu ao período como "a Libertação" - libertação esta que está longe de ter passado em branco em seu manifesto sobre o destino do autor.

Essencialmente, o final da década de 1960 na França é marcado por uma transição geracional bastante nítida, ligada ao sensacional progresso da alfabetização e à extraordinária corrida para a Universidade, que aprofundaram enormemente as diferenças entre pais e filhos, seja no que se refere à visão de mundo, aos hábitos e valores adotados. O jovem universitário não representava mais um pequeno percentual da população em mera transição para as obrigações adultas, mas uma classe composta por uma massa de estudantes ainda sem espaço definido na sociedade. $\mathrm{O}$ abismo geracional se agrava se considerarmos a diferença de mentalidade entre aqueles que, tendo enfrentado a $2^{\text {a }}$ Guerra Mundial, presenciavam um momento incomparavelmente mais estável e com ares de prosperidade nos anos 60 , e a geração pós-guerra, ávida por encontrar sentidos na eleição de inimigos. $\mathrm{O}$ ressentimento contra um tipo de autoridade, representado pela própria universidade, alimentou o radicalismo entre uma classe social curiosamente não afetada diretamente pela insatisfação econômica. Na França, a associação da figura de De Gaulle com a de um tirano, embora comum, era injustificável em muitos aspectos, e derivava da necessidade de união de toda a esquerda, que buscava afirmar-se e instaurar um governo popular que discriminasse qualquer forma de afirmação de poder pessoal. Naquele momento, ainda não estava claro que o inimigo não era mais uma pessoa (os fantasmas de Stálin, Hitler e Mussolini) ou categoria social (a monarquia, a burguesia), mas algo invisivelmente nefasto, sem rosto, que ali- 
mentava e educava a juventude rebelde: o poder socioeconômico - ditador de hábitos, necessidades, valores e modos de relações humanas.

É nessa atmosfera libertária, em que o argumento de autoridade perdia a razão, e é empenhado em desabonar quaisquer formas de poder, que Barthes escreve "A morte do autor".

Não é difícil compreender a inclinação ideológica de seu gesto, bem como a vinculação que estabelece entre a figura autoral e a imagem de um tirano. Seu manifesto é fruto de um momento coletivo de grande élan revolucionário. Não por acaso, ele está entremeado de expressões que apontam para um mesmo universo conotativo: o autor é o dono de um Império muito poderoso, diz Barthes. Portanto, a autoria é considerada sinônimo de autoridade, aprisionamento, restrição, centralização, e contra ela operam termos como "destruição", "apagamento", "desligamento", "afastamento" e "dessacralização".

A iniciativa de se afastar de quaisquer formas de poder é representativa em Barthes. Em sua aula inaugural no Colégio da França (1977), ele retoma o mesmo tema: "Uma outra alegria me vem hoje, mais grave porque mais responsável: a de entrar num lugar que pode ser dito rigorosamente: fora do poder." ${ }^{27}$ Essa afirmação se faz presente diante da constatação de que o conjunto de rupturas conquistadas pela sociedade intelectual há pouco menos de uma década do pronunciamento de sua "aula" não produzira um desligamento do poder, pelo contrário:

...evidenciou-se que, à medida que os aparelhos de contestação se multiplicavam, o próprio poder, como categoria discursiva, se dividia, se estendia como uma água que escorre por toda a parte, cada grupo opositor tornando-se, por sua vez e à sua maneira, um grupo de pressão, $\mathrm{e}$ entoando em seu próprio nome o próprio discurso do poder. ${ }^{28}$

Os produtos social, cultural e sexual da ruptura não se traduziam: "vangloriavam-se de pôr em evidência o que havia sido esmagado, sem ver o que, assim fazendo, se esmagava alhures." ${ }^{29}$ Sua famosa "Aula" é em parte um modo de justificar o texto como espaço de libertação total das formas de poder: "Se a semiologia de que falo voltou então ao Texto é que, nesse concerto de pequenas dominações, o Texto lhe apareceu como o próprio índice de despoder." 30 Barthes definia ao mesmo tempo um posicionamento diante da literatura e a sua natureza. A literatura lhe serve, assim, como estado privilegiado da linguagem, como escritura emancipada de um autor, que "permite ouvir a língua fora do poder", e esse poder é representado, no âmbito da linguagem, pelo "mito da criatividade pura", ou seja, o homem de gênio.

A matéria em jogo é fundamentalmente ideológica: a literatura deve distanciar-se da palavra gregária, dos donos do sentido, e ser encarada como escrita

\footnotetext{
${ }^{27}$ BARTHES, R. Aula. Trad. e posf. de Leyla Perrone-Moisés. 7. ed. São Paulo: Cultrix, 1997, p. 9.

${ }^{28}$ Ibid., p. 34.

${ }^{29}$ Ibid., p. 34-5.

${ }^{30}$ Ibid., p. 35.
} 
"longe dos topoi da cultura politizada". ${ }^{31}$ A ideia de libertação insere-se, de resto, num conjunto de atitudes que se traduzem de modo similar, tal como a de se buscar a emancipação do estado com relação à igreja, do cidadão com relação ao estado, do homem com relação a deus.

Se o pensamento intelectual nesse momento dirige-se para a necessidade de deixar-se guiar a si mesmo, sua radicalização será imaginar a possibilidade de o texto falar por si. Diante dessa liberdade, também o papel do professor deve ser revisto, e Barthes se mostra atento a isso: "O que eu gostaria de renovar, cada um dos anos em que me será dado aqui ensinar, é a maneira de apresentar a aula ou o seminário, em suma, de 'manter' um discurso sem o impor."32

É ainda na Aula, ministrada com distanciamento do momento de publicação do texto aqui enfocado, que Barthes associa diretamente a tese da "morte do autor" com os acontecimentos ocorridos no ano de sua escrita:

Por um lado, e antes de mais nada, desde a Libertação, o mito do grande escritor francês, depositário sagrado de todos os valores superiores, desgasta-se, extenua-se e morre pouco a pouco com cada um dos últimos sobreviventes do período entre as duas Guerras; é um novo tipo que entra em cena, que não se sabe mais - ou não se sabe ainda - como chamar: escritor? Intelectual? Escriptor? ${ }^{33}$

A desmistificação de verdades, práticas e modos de ver é um procedimento típico em Barthes. Talvez o grande ponto de união entre seus textos seja a perseguição ao senso comum, aos mecanismos naturais de cristalização de ideologias. Matar o autor é uma decisão que evidencia sua fuga do consensual, e a ruptura com os hábitos foi sempre uma prática autojustificável para o crítico. Autoria e autoridade só poderiam ter sido tomadas como sinônimos por ele.

Mas se a exclusão do autor da recepção da obra literária foi uma prática que a geração de 68 sedimentou na crítica literária, este duplo retrospecto, tanto retórico quanto histórico, permite-nos compreender que o grande gesto teórico da morte do autor, uma vez tornado consenso estruturalista e formalista para as sucessivas gerações de críticos, muitos dos quais ainda atuantes, deve ser encarado como um passo para que o autor renasça sob uma perspectiva ao mesmo tempo menos projetiva e mais humanizada.

${ }^{31}$ Ibid., p. 35.

32 Ibid., p. 43.

${ }^{33}$ Ibid., p. 41. 